\title{
NARRATIVES OF BIRTH IN SWEDISH POPULAR AUTOBIOGRAPHY
}

\author{
Bo G. Nilsson
}

My paper concerns a corpus of workers' autobiographical writings at the Nordiska Museet in Stockholm, Sweden. In 1945, the Nordiska Museet began to systematically collect workers' narratives (Nilsson 1996). The museum, in collaboration with almost twenty labour unions, urged retired workers to relate the stories of their lives in writing and issued a series of guidelines suggesting appropriate themes. By 1960, the collection of Workers' Recollections in the museum amounted to approximately 2000 written narratives, comprising more than 30,000 pages of text. The narratives are mostly personally written life stories, in which the narrators, using the first person, tell of their experiences. A significant proportion, however, were written down on behalf of the narrators by local informants who then sent the material to the museum.

The primary context for these workers' recollections was the museum's investigation into Swedish cultural history and social life. During the inter-war years ethnologists and museum curators began to change the thematic focus of investigation, so as to include the history of the modern working class in addition to the old peasant culture. This new perceptual field was necessitated by the social change that Swedish society was going through at the time. The first phase of industrialisation had been completed and the industrial working class had become one of the main forces in society. When the Social Democrats assumed governmental responsibility in 1932 the construction of a modern welfare state began. In my thesis, Workers' memories in the Swedish Folkhem. A study of the historical and discursive preconditions of Swedish working class biography (Nilsson 1996), I have shown how descriptions of the old class society gave the development of modern welfare its legitimacy, creating a historic situation where the workers' class-based "weexperiences" became relevant for the society in large.

If my earlier project thus concerned a historic and discursive contextualisation of the collection of material, my present work 
Bo G. Nilsson

analyses these workers' recollections as narratives. In this paper I am going to focus on ways in which narrators introduce themselves in their texts. The paper represents a study in progress, and so far I have only been able to analyse a small part of the material, about thirty written life-stories by workers in the book-binding industry.

As a theoretical tool to examine these narratives I use some of the concepts put forward by the so-called Bakhtin Circle during the inter-war years. The Russian literary theorist Mikhail Bakhtin developed a method of studying themes of utterances. The general question he proposed was as follows: how does the narrative approach reality and reproduce it with decided emphasis and socially created values? He summarised his answer in the concept of chronotope. The chronotope does not deal with any definite stylistic device or formal verbal structure but is concerned with seeking an inner structuring principle to analyse the way in which people, events and surroundings are described in narratives and in whole genres. It is a matter of searching for an organising centre for the narrative. Bakhtin writes that, in the chronotope,

spatial and temporal indicators are fused into one carefully thought-out, concrete whole. Time, as it were, thickens, takes on flesh, becomes artistically visible; likewise, space becomes charged and responsive to the movements of time, plot and history [...] It can even be said that it is precisely the chronotope that defines genre and generic distinctions [...] The chronotope as a formally constitutive category determines to a significant degree the image of man in literature as well. The image of man is always intrinsically chronotopic. (Bakhtin 1981b: 84-85)

\section{SIMPLE INTRODUCTION - ELEMENTS OF EMPLOTMENT}

The organising centre of an autobiographical narrative is of course its principal character or hero. For that reason the starting point of the story is the introduction of the hero. Let me give you two examples of the way narrators generally introduce themselves into the narrative: 
Narratives of Birth in Swedish Popular Autobiography

I was born on 11th July in the parish of Östra Nöbbelöv, in the province of Kristianstad, more precisely in the village of Gislöv.

I was born in Stockholm, at 57, Stora Badstugatan (nowadays Sveavägen) on 10th August 1885.

Place and date of birth, sometimes supplemented by name, is the information given in these short introductions. These scanty notes could, using the terminology of Hayden White in Metahistory (1973: 5-7) be regarded as simple "chronicles", as open-ended and uncoded registers of events, but they are already elements of an emplotment, albeit in very embryonic form. They mark off the events contained in the autobiographical narrative, differentiating it from other narrative forms. The chronotope is of a concrete kind, it places the principal character in a familiar biographical time and in an equally familiar geographical space. This indicates that the autobiographical narrative moves within socially and geographically determined everyday settings, unlike, for example, folk tales which have a vague and indefinite location ("once upon a time"), or myths, which explain the creation of a certain reality with reference to a supernatural intervention ("in the beginning God created heaven and earth").

The movement towards emplotment includes using the techniques of figurative language, by means of which the narrator can project meaning, rendering the strange and distant past familiar and comprehensible (White 1978: 94). This is done by linking the distant past with culturally familiar worlds, as when one female narrator, Anna Törnqvist, tells of her birth in a maternity hospital for the poor of Stockholm around Christmas of 1883. She tells us that she and her mother were brought home by an aunt on Christmas Eve, and concludes, "so I was a real Christmas present". This reflection, of course, adds some literary quality to her narrative. But it also reminds us of the fact that the chronotope is much more than a set of temporal and spatial determinations. It also, importantly, incorporates a sphere of meaning, and involves some assigning of value (Bakhtin 1981b: 257). Evaluations establish the relations of the near and distant, high and low, strange and familiar. In this case the new-born baby is linked with a very positive evaluation, she is likened to a Christmas present, even though the circumstances of her appearance on earth is portrayed as rather bleak. Narratives of birth, as Philippe Lejeune has noted, do indeed pose questions of an 
Bo G. Nilsson

existential kind: where do I come from, what is my relation to my parents and my siblings? And social origins: to what social class do I belong, was I born inside or outside marriage, was I wanted or not (Lejeune 1986)?

The small example just given also alerts us to the fact that autobiographical narratives often draw on other people's experiences and stories. When we read Anna's comment that she was a real Christmas present, we can easily imagine that this must have been part of an answer that her mother often gave her, when she asked about the circumstances of her birth. With Bakhtin's terminology in his essay The Problem of Speech Genres we can say that her mother's utterance is a primary (simple) genre, which is absorbed and digested by Anna when she constructs her secondary and more complex autobiographical narrative (Bakhtin 1986: 61-62).

\section{SHIFTING ALLIANCES}

An autobiographical narrative has three main actors: the writer, the reader and the "hero" or principal character. Normally, of course, the relation between narrator and main character is distinguished; in the workers' recollections, by a high degree of proximity. The narrator identifies himself with the main character - the autobiographical "I" - and directs himself to the recipient - the museum. But the narrative of birth takes on a more complicated structure when another person is introduced as the main character. The leading part can temporarily be given to the mother.

One of the bookbinding workers began his recollecting narrative in the following way:

11th September 1880 was a great day on Orust. It was on that day, namely, that my mother, Anna Sofia Nilsdotter in Stala, bore a son whom she christened Oscar. The father of this wonderchild-to-be was first mate Olof Anton Nilsson...

Two things are important in the image of the main character created here by the narrator. In the first place, he is introduced in the third person, as "Oscar". The narrator distances himself from the main character and achieves a reversal of alliances in the triangu- 
Narratives of Birth in Swedish Popular Autobiography

lar drama of narrator - main character - reader. The narrator detaches himself from his basic unity with the hero and enters into a temporary alliance with the reader, so that these two together now observe little Oscar. The construction with the main character in the third person is, then, a device by which the narrator can draw his reader along with him in shared sympathy for, and interest in, the hero. This is one of the rhetorical categories of autobiographical narrative and is fairly common in workers' recollections.

In the second place, Oscar Olsson introduces himself in the narrative using a light, almost bantering tone ("a great day", "the wonder-child-to-be"). It is a matter of playing with the parents' perspective and with one's own identity, and lends the account a light and untroubled air. The narrator takes on the perspective of the parents and allows it to be permeated by his own ironical detachment. By means of these words and this device two voices speak simultaneously: this of the parents and this of the narrator. This is an example of what Bakhtin calls hybrid construction (Bakhtin 1981a: 304). Light, ironical detachment is one of the main devices used by narrators to introduce the main character - himself - in the narrative. Another is sensitive earnestness, full of pathos, where the narrator seeks to persuade the reader to sympathise with the hero.

This simple and direct way of introducing oneself - by way of name, date and place of birth - is by far the most common in the collection of workers' recollections at the Nordiska Museet. But there are other options, the foremost of these involving weaving the introduction of oneself in an account of one's family and/or parents, a method chosen by approximately $5-10$ percent of the narrators. There are, of course, culturally significant models for this choice of narrative structure, e.g. in the way genealogical tables are often given in autobiographies written by members of the upper classes, or the pedigree of Joseph presented in the Biblical Gospel of St. Matthew.

\section{STRIDES TOWARDS EMPLOTMENT}

Longer strides towards emplotment are taken by those narrators who link elements of a foreboding nature with their narratives of birth. A very common element of this kind in the Swedish workers' 
Bo G. Nilsson

memories is the death of one of the parents, most often the father, an event which has affected the lives of an astonishingly high percentage of the narrators. This observation corroborates with the findings of Monika Bernold in her study of written life-stories by women from the lower strata of society, collected by the Dokumentation lebensgeschichtlicher Aufzeichnungen in Vienna. In these life-stories, women often told of deaths in their families that happened when they were only small children. The loss of one of the parents had long-lasting consequences for the distribution of tasks within the household, and often meant that the family had to face economically insecure conditions, if not outright poverty (Bernold 1993: 12-13).

Events of a foreboding nature are used to connect different parts of a worker's recollections, often with the intent of explaining the course the narrator's life necessarily had to take after such an unhappy start. Here is an excerpt from Carl Lindvall's story:

On 20th March, 1865 there was great joy in a simple working home in the town of Nyköping. A fine baby boy had come into the world there in the Lindvall family. The father, who worked in a smithy, was very happy, according to what my mother told me. And so a year went by and the happiness over the boy lasted. But can you tell me of any joy which lasts forever? After perhaps a year my mother was widowed.

A smallpox epidemic arrived and raged in the town and surrounding area, and this was how my father ended his days, to the great sorrow of his surviving wife. The boy, who was me, and who was baptised Carl Erik, also got a bit of the epidemic, and lay nearly unconscious for two days and nights, but this time got away with his life, though he had some small scars on his nose as a souvenir while he was growing up. And now arose the question of how mother was to cope with her little boy in future?

Well, she had to part with him, there was nothing else for it, and she herself had to seek a maid's position, as it was called at the time. In her home area there lived a smallholder's family who were in some way related to father, and whom she knew to be decent, kind people. They had a smallholding belonging to Husby Manor, whose owner was Count Wachtmeister. The smallholding was called Nöa [in Swedish, short for "trouble" or "want"] 
Narratives of Birth in Swedish Popular Autobiography

but there was nothing to complain of there. After some negotiations mother took her boy with her and went there and these good old people took me in and there I had my parental home and a better one I could never have had and I shall remember these good people with gratitude and love to the end of my days. Peace to their memory!

What we have here is, again, the concrete chronotope of the autobiographical narrative. What is being told can mostly be traced back to the information that Carl's mother has given him, so here once again it's a case of primary genres being absorbed by and digested into a more complex and secondary genre. Carl uses the narrative device of separating the narrator from the main character, and introducing himself in the third person, as did Oscar Olsson. But there is a difference in their way of using this device. Oscar created what we could dub an "inner distance" or detachment between himself as narrator and his parents, jokingly undermining the perspective of his parents and his own identity. Carl, on the other hand, displays an unabridged and unambiguous solidarity with the fate of his parents, and of himself, and tries to move his readers into embracing the same heart-felt pathos. This feeling is built up with the help of figurative language, projecting culturally loaded images of "a simple working home" and "a fine baby boy" onto the readers.

The change from good to bad is accompanied by the proverbial "can you tell me any joy which lasts forever". With the help of the proverb the narrator has the "official voice" of culture confirm the validity of his experiences with the traditional cultural heritage, people's wisdom. The family's time of happiness ends: the mother becomes a widow and the "fine baby boy" gets scars on his nose after a smallpox epidemic. The scars remain as visible traces in his face, telling the story of the terrible and decisive ordeal he went through as a small child.

\section{DRAMATIC BIRTH}

Another narrator, Eric Bengtsson, develops the motif of an introductory test or ordeal further: 
Bo G. Nilsson

On Sunday, 9th February, 1890 there was great commotion in the little flat at 100, Norra Vallgatan, where Carl August Bengtsson, machine assistant at the Roller Mill, lived with his wife Cecilia, nee Larsson, their sons Karl Edvin and Ernst Hugo and their daughter Elise Gunhild. The 27-year-old young wife had given birth to her fourth child, a boy, who had now lain there all day without showing any interest in this important event. Not the least sound had been heard from him, and the midwife explained: "he won't survive the night, best fetch the parson and get the child christened, if one doesn't want him to be tucked down a heathen."

A message went to young Parson Meier in St. Peter's parish, who promised to come after Evensong. In the interval that passed, my aunt (father's sister) and her husband, Ludvig Frost, the tanner, arrived. He was always particularly keen on alcohol, both then and later on, and thought that one could pass the time by drinking a glass of brandy and toasting to a "happy outcome". Whether he or anyone else present suggested it, or anyone thought they knew that brandy would probably be good for children in such circumstances, anyhow I appear, according to the story, to have really been given a spoonful of brandy and they assure me that I opened wide for more. The parson came and I was christened Erik Konrad. Whether it was the brandy, or the christening ceremony or the fact that my eldest brother fell down the stairs outside with a crash in the middle of the christening; my brothers and sister had been sent to my Grandmother (father's mother), who lived further along the corridor on the second floor, for the whole day, he was now running to Grandmother and the result was that he went flying head over heels down the steps; this was how my curiosity about life was awoken. I got better and three months later bore my mother company on a sea trip on the paddle steamer Gylfe to Copenhagen, where Father had got a job at Sortedamm Mill. It was to be the city where I spent my childhood and years of growing up. A time of all sorts of experiences, but nothing at all to do with bookbinding; the fact that I include the events of this time in my account anyway may perhaps seem unjustified?

The whole event is embedded into Eric's first day in life, but through the concluding look ahead it is connected with Eric's biography as a 
Narratives of Birth in Swedish Popular Autobiography

whole. The dramatic plot reaches its peak with the midwife's cue that Eric probably will not survive the night and the parson is sent for to baptise him privately. The dramatic tension is relieved and the narrative given a clearly humorous accent when Eric is spoonfed with brandy and "opens wide for more". This light and playful tone has already been prepared for in the preceding paragraph, when little Eric is said to have lain there all day "without showing any interest in this important event". What is being projected is Eric's "inner detachment" both from the perspective of his parents (for whom this must have been a very serious time) and his own identity and existence. Eric's aloofness in relation to the seriousness of the events is underlined when he suggests that it took some brandy or his brother's crash down the steps to really "awaken his curiosity about life."

Just as in the preceding examples, Eric is introduced into the narrative in the third person. It is not until the dramatic tension is resolved that he steps forward as the "I" of the autobiographical narrative. The whole episode basically represents other people's experiences and stories. It is not difficult to imagine that this story had been told many times, accompanied by laughs and happy smiles, at family gatherings, and that it had formed part of a collective narrative tradition. From its existence as a primary, everyday oral genre Eric has absorbed it into his autobiographical account, a secondary, more complex and written genre.

\section{CONCLUSION}

In this paper I have tried to analyse narratives of birth in the workers' recollections, archived at the Nordiska Museet in Stockholm. I have focused on the image of the principal character - the autobiographical "I" - using the theoretical concept of the chronotope. I have specifically pointed out the usefulness of studying the portrayal of the main person as an outcome of varying relationships between writer, "hero" and reader. The narrative device of introducing the autobiographical "I" in the third person is, for example, part of the narrator's rhetorical armoury. It is used to effect a reversal of alliances, so that the narrator breaks his basic unity with the "hero" and enters temporarily into alliance with the reader in 
Bo G. Nilsson

order to draw him along in shared sympathy for, and interest in, the hero.

I have distinguished two kinds of relationships between the writer and hero. In one, the main character is depicted with full and earnest sympathy; in the other the relationship presents playful and often humorous detachment. The nature of this relationship shapes the image of the autobiographical I as presented in the narrative. However, on the chronotopic level images given of the hero with whichever means are similar. In all cases the narrators have had to face difficulties already at the very beginning of their lives. This is one side, the negative, of the dual image given of the heroes. The positive side of the image is that the heroes have survived and been able to go on with their lives. They were put to test, but they made it. This dual image of being able to survive and in some cases even to grow stronger in spite of bad luck, hardships and the external conditions imposed upon the workers by the class society, is an image that permeates the majority of the workers' memories at the Nordiska Museet, whether in narratives of birth or as the narrators touch upon other parts of their life-stories.

\section{References}

Bakhtin, M. 1981a. Discourse in the Novel. The Dialogic Imagination. Four essays. Bakhtin, M. (ed.). Austin: University of Texas Press, pp. 259422.

Bakhtin, M. 1981b. Forms of Time and of the Chronotope in the Novel. The Dialogic Imagination. Four essays. Bakhtin, M. (ed.). Austin: University of Texas Press, pp. 84-258.

Bakhtin, M. 1986. The Problem of Speech Genres. Speech Genres and Other Late Essays. Bakhtin, M. (ed.). Austin: University of Texas Press, pp. 60-102.

Bernold, Monika 1993. Anfänge. Zur Selbstverortung in der popularen Autobiographik. Historische Anthropologie 1:1, pp. 5-24.

Frank, Gelya 1996. Myths of Creation: Construction of Self in an Autobiographical Account of Birth and Infancy. Imagined Childhoods. Self and Society in Autobiographical Accounts. Gullestad, Marianne (ed.). Oslo: Scandinavian University Press, pp. 63-90.

Lejeune, Philippe 1986. Récits de naissance. Moi aussi. Paris: Éditions du Seuil, pp. 310-337. 
Narratives of Birth in Swedish Popular Autobiography

Nilsson, Bo G. 1996. Folkhemmets arbetarminnen. En undersökning av de historiska och diskursiva villkoren för svenska arbetares levnadsskildringar. Stockholm: Nordiska museets förlag.

White, Hayden 1973. Metahistory. The historical imagination in nineteenth-century Europe. Baltimore \& London: The Johns Hopkins University Press.

White, Hayden 1978. The Historical Text as Literary Artefact. Tropics of Discourse. Essays in cultural criticism. Baltimore \& London: The Johns Hopkins University Press, pp. 81-100.

The article was presented at the SIEF conference, 23-27 April 2001. 